\title{
FUNGSI BADAN PERMUSYAWARATAN DESA (BPD) DALAM PEMBENTUKAN PERATURAN DESA DI DESA SANDING KECAMATAN TAMPAKSIRING KABUPATEN GIANYAR
}

\author{
Agus Leo Adi Wibawa, Ida Ayu Putu Widiati, A.A. Sagung Laksmi Dewi \\ Fakultas Hukum, Universitas Warmadewa, Denpasar - Bali, Indonesia \\ widiatidayu@yahoo.co.id, laksmidewii29@gmail.com
}

\begin{abstract}
Abstrak
BPD mempunyai tugas membuat aturan bersama kades, mengambil dan mengusulkan ide masyarakat, oleh karenanya BPD sebagai badan permusyawaratan yang berasal dari masyarakat desa, di samping melaksanakan tugasnya sebagai perantara antara Kades dengan masyarakat desa, juga menjalankan fungsi utamanya, yakni fungsi representasi. Tujuan penelitian ini untuk mengungkap fungsi Badan Permusyawaratan Desa dalam pembentukan Peraturan Desa serta hambatan pelaksanaan fungsi Badan Permusyawaratan Desa dalam pembentukan peraturan Desa di Desa Sanding Kecamatan Tampaksiring Kabupaten Gianyar. Tipe penelitian yang digunakan adalah penelitian hukum empiris dengan menggunakan pendekatan yuridis sosiologis. Teknik pengumpulan data dilakukan dengan penelitian lapangan. Sumber data yang digunakan berupa primer dan sekunder yang kemudian dianalisis dengan sistematis dan mengaitkannya dengan bahan hukum lainnya. Hasil penelitian mengungkapkan bahwa fungsi Badan Permusyawaratan Desa dalam pembentukan PerDes antara lain dapat menyusun dan mengusulkan rancangan Peraturan Desa. Rancangan Peraturan Desa dapat diusulkan oleh anggota BPD kepada pimpinan Badan Permusyawaratan Desa untuk ditetapkan sebagai rancangan Peraturan Desa usulan BPD. Hambatan pelaksanaan fungsi dalam pembentukan peraturan Desa yaitu pertama hambatan secara yuridis antara lain: Minimnya pengetahuan dan pengalaman anggota BPD, Pemahaman terhadap peraturan perundang-undangan tentang desa anggota BPD masih kurang, Banyak anggota BPD yang tingkat pendidikannya rendah dan yang kedua secara non yuridis yaitu Kehadiran para anggota BPD dalam penyusunan dan Pemahaman terhadap dasar hukum pembentukan peraturan desa masih rendah dan Permohonan potensi desanya juga rendah.
\end{abstract}

Kata Kunci: Badan Permusyawaratan Desa, Peraturan Desa, Kabupaten Gianyar

\begin{abstract}
$B P D$ has the task of making rules with the village head, taking and proposing community ideas, therefore the $B P D$ as a deliberation body originating from the village community, in addition to carrying out its duties as an intermediary between the village head and the village community, also carries out its main function, namely the function of representation. The purpose of this research is to reveal the function of the Village Consultative Body in the formation of Village Regulations and the obstacles to implementing the functions of the Village Consultative Body in the formation of Village regulations in Sanding Village, Tampaksiring District, Gianyar Regency. The type of research used is empirical legal research using a sociological juridical approach. The data collection technique was carried out by field research. The data sources used are primary and secondary which are then analyzed systematically and linked to other legal materials. The results of the research reveal that the functions of the Village Consultative Body in forming the Village Regulations include, among others, being able to prepare and propose draft Village Regulations. Draft Village Regulations can be proposed by members of the BPD to the leadership of the Village Consultative Body to be determined as a draft Village Regulation proposed by the BPD. Barriers to the implementation of functions in the formation of village regulations, namely, first, juridical obstacles include: Lack of knowledge and experience of BPD members, understanding of the laws and regulations regarding villages of BPD members, many BPD members with low levels of education and secondly, non-juridically, namely the presence of BPD members in the preparation and understanding of the legal basis for the formation of village regulations is still low and the application potential of the village is also low.
\end{abstract}

Keywords: Village Consultative Agency, Village Regulation, Gianyar Regency 


\section{PENDAhuluan}

Penyelenggaraan suatu Pemerintahan di era ini pada intinya adalah proses demokrasi. semua yang berawal dari proses kalangan atas sampai bawah, dalam pola pikir yang terbalik dan konsep yang sangat jauh berbeda sebagaimana diatur dalam pasal 18 ayat (7) Undang-Undang Dasar Republik Indonesia Tahun 1945 (Wijaya, 2004). Peraturan desa yang dijalankan oleh semua pemangku atau aparat desa dalam ini yang berpedoman pada UUD. Peran desa yang selama ini menjadi peran No. 2, semua berubah dengan adanya undang-undang yang baru. Dulunya yang memegang kendali adalah dipusat sekang bias dibuat atau bias diotonomikan didalam desa. Segala putusan bias diselesaikan ditingkat desa antara kepala desa dan BPD dengan menyerap usulan masyarakat dengan kesepakatan bersama. Asal usul keberagaman desa:

1. Keanekaragaman, dicocokan dengan asal muasal dan situasi sosial budaya masyarakat setempat.

2. Partisipasi, bahwa menjalankan dan mengembangkan desa wajib mengajak aktif peran masyarakat dan ikut menanggung jawabkan semua terutama antar warga.

3. Otonomi asli, bahwa hak pemerintah dalam menjalankan dan mengayomi masyarakat didasarkan pada hak asal muasal dan nilai-nilai sosial yang terdapat pada masyarakat setempat, namun harus diselenggarakan dalam perspektif administrasi desa.

4. Demokrasi, artinya menjalankan pemerintahan dan pelaksanaanperkembangan di desa harus menampung inspirasi-inspirasi masyarakat terus dipilih untuk dilaksanakan melalui BPD dan lembaga kemasyarakatan sebagai mitra pemerintah desa.

5. Pemberdayaan masyarakat, artinya menjalankan dan mengembangakan untuk meningkatkan kesejahteraan dan potensi masyarakat melalui penerapan kebijakan, program dan kegiatan yang sesuai dengan pokok masalah dan prioritas kebutuhan masyarakat (Fauzan, 2010).

Pemerintahan desa harus melaksanakan peraturan undang-undang yang keterkaitan dengan desa akan tetapi peraturan undang-undang itu tidak bisa langsung diterapkan. Hal ini karena desa berbeda kondisi sosial, politik, dan budayanya. Dalam melaksanakan dan pengambil keputusan di desa dilakukan dengan 2 metode (Kushandajani, 2008). satu, putusan-putusan yang beraspek sosial, yang mengingat secara iklas, tanpa hukuman yang jelas. Kedua, putusan-putusan yang dibuat oleh instansiinstansi resmi desa yang dibuat untuk melakukan fungsi menjalankan keputusan. Keputusan yang dihasilkan sangat beragam dalam masyarakat desa, semua hasil keputusan diambil berdasarkan kemupakatan, sebagaiman sebelum itu diambil keputusan diusulkan oleh orang yang berpengaruh dalam lingkungan atau orang yang mampu dan berkompeten. Adapun bentuk 2, keputusan-keputusan didasarkan kesepakatan dari semua pihak yang ada didesa, contohnya musdes. Semua aturan yang dilakuakn akan mengakibatkan masalah yang berliku tajam dalam penerapan aspek desa. semua peraturan yang dibuat atas kesepakatan bersama, kemudian dijalankan oleh setiap stekholder sehingga semua kegiatan akan berjalan dengan terstruktur dan tersistem. Semua putusan yang akan dilakukan didesa dibuat oleh oknum-oknum tertentu. Semua proses itu dilakukan oleh yang berwenang dan memeng diberikan wewenang. pembuat peratuan yang mengatur semua kegiatan desa. Ini merukan implementasi dari aturan yang ada diatas sehingga tidak melanggar UUD.

BPD berfungsi merancang aturan desa bersama kades, mengambil dan menyimpan aspirasi masyarakat, maka dari itu BPD sebagai lembaga yang mewakili desa dalam pembuatan peraturan yang akan diterapakan, di samping menerapakan tugasnya sebagai perantara antara kepala desa dengan masyarakat desa, juga menjalankan fungsi utamanya, yakni fungsi representasi (perkawinan) (Wasistiono \& Tahir, 2006). Akan tetapi terkadang semua yang telah disetujui oleh pemerintah desa dengan BPD tidak terjadi seperti harapan masyarakat. Sehingga menyebabkan terjadi beberapa masalah yang terjadi didesa.

Menurut Rodhiyah \& Harir (2016) peraturan desa merupakan bentuk regulasi yang dikeluarkan oleh pemerintah desa sebagaimana kabupaten membuat peraturan daerah dan pada dasarnya Peraturan desa ditetapkan oleh kepala desa bersama bersama BPD. Lebih lanjut, dibentuknya BPD bertujuan untuk mendorong terciptanya perkongsian antara warga dan pemerintah desa sebagai lembaga yang berperan dalam menampung dan menyampaikan aspirasi masyarakat (Malik, 2020). Hal ini sejalan dengan pendapat Patrasius (2019) bahwa Badan permusyawaratan Desa (BPD) berperan sebagai wakil rakyat di desa adalah sebagai tempat bagi masyarakat untuk menampung segala keluhankeluhannya dan kemudian menindaklanjuti aspirasi tersebut untuk disampaikan kepada instansi atau lembaga yang terkait. 
Berdasarkan uraian diatas, maka tujuan penelitian ini untuk mengungkap fungsi Badan Permusyawaratan Desa dalam pembentukan Peraturan Desa serta hambatan pelaksanaan fungsi Badan Permusyawaratan Desa dalam pembentukan peraturan Desa di Desa Sanding Kecamatan Tampaksiring Kabupaten Gianyar.

\section{METODE PENELITIAN}

Tipe penelitian yang dipergunakan adalah penelitian hukum empiris sebab dalam penelitian ini disamping berdasarkan teori yang ada kemudian diamsumsikan tanyajawab dengan narasumber dan data di lapangan (Soekanto, 1986) dengan menggunakan pendekatan yuridis sosiologis yang tujuannya memperoleh pengetahuan hukum secara empiris dengan observasi kepada obyek yang dituju (Fauziah, 2020). Teknik pengumpulan data dilakukan dengan wawancara kepala Desa Sanding, Kecamatan Tampaksiring Kabupaten Gianyar. Sumber bahan hukum yang digunakan berupa bahan hukum primer yang berpedoman terhadap UU dan keputusan yang mengikat, bahan hukum sekunder yang didapatkan melalui jurnal hukum dan buku hukum. Setelah data dikumpulkan, maka selanjutnya data di analisis dengan sistematis dan mengaitkannya dengan bahan hukum lainnya.

\section{HASIL DAN PEMBAHASAN}

\section{Fungsi Badan Permusyawaratan Desa dalam Pembentukan Peraturan Desa}

Pada dasarnya BPD mmempunyai kewenangan menetapkan peraturandesa bersama Kepala Desa, menampung dan menyalurkan aspirasi masyarakat, oleh sebab itu BPD sebagai badan permusyawaratan yang berasal dari masyarakat desa disamping menjalankan fungsinya sebagai jembatan penghubung antara Kepala Desa dengan masyarakat desa juga harus melaksanakan fungsi utamanya yakni fungsi representasi (perwakilan) (Setiawati, 2018).

Menurut I Dewa Gde Mahendra, Kepala Desa Sanding, Kecamatan Tampaksiring Kabupaten Gianyar mengatakan bahwa fungsi penyusunan rancangan Peraturan Desa ditetapkan oleh kepala Desa dan BPD dalam rencana kerja Pemerintah Desa. Lembaga kemasyarakatan, lembaga adat dan lembaga desa lainnya di desa dapat memberikan masukan kepada Pemerintah Desa dan atau BPD untuk rencana "Penyusunan draf Peraturan Desa. Penyusunan draf Peraturan Desa diprakarsai oleh Pemerintah Desa. setelah semua terakomodir dengan baik susunan Peraturan Desa yang telah disusun, sangat wajib dipublikasikan ke warga kemudian dikonsulkan kecamat. Masukan dari masyarakat desa dan camat digunakan Pemerintahan Desa untuk tindak lanjut proses menyusun draf perdes. Rancangan PerDes yang telah dikonsultasikan disampaikan Kepala Desa kepada BPD untuk dibahas dan disepakati bersama. (wawancara dengan I Dewa Gde Mahendra, Kepala Desa Sanding, Kecamatan Tampaksiring Kabupaten Gianyar, tanggal 3 April 2020).

Badan Permusyawaratan Desa (BPD) dapat membuat dan merancang rancangan PerDes. Rancangan PerDes. Rancangan Peraturan Desa dapat diusulkan oleh anggota BPD kepada pimpinan Badan Permusyawaratan Desa (BPD) untuk ditetapkan sebagai rancangan Peraturan Desa usulan Badan Permusyawaratan Desa (BPD) (wawancara dengan I Dewa Gde Mahendra, Kepala Desa Sanding, Kecamatan Tampaksiring Kabupaten Gianyar, tanggal 3 April 2020). Badan Permusyawaratan Desa (BPD) mengundangkan Kepala Desa untuk memusyawarahkan rancangan PerDes. Dalam hal ini dapat rancangan Peraturan Desa prakarsa. Rancangan Peraturan Desa yang telah dibahas dan telah disetujui oleh semua pihak tidak boleh ditarik kembali kecuali atas persetujuan antara Pemerintah Desa dan BPD, sehingga aturan yang dibuat sangat kuat dan memiliki kekuatan hukum yang mampu dengan tegas dilaksanakan didesa setempat.

Sekretaris Desa menetapkan peraturan desa dalam lembaran desa. Peraturan ini mulai berlaku sejak diedarkan sehingga memiliki kekuatan hukum yang sah dan dapat. mengumumkan peraturan dilaksanakan oleh Pemerintah Desa dan BPD sejak penetapan, Penyusunan Rancangan Peraturan Desa, pembahasan Rancangan Peraturan Desa, hingga menetapkan Peraturan desa. mengumumkan dimaksudkan sebagi bentuk informasi kepada masyarakat sehingga dari masyarkat dapat memberi ide kepada aparat dalam melaksakan pemerintahnnya dan tercipta keterbukaan yang sangat transparan.

\section{Hambatan Pelaksanaan Fungsi Badan Permusyawaratan Desa dalam Pembentukan Peraturan Desa}

Sesuai wawancara dengan I Wayan Wijaya BPD Bidang Pembangunan yang mengatakan, yang menjadi hambatan pelaksanaan fungsi Badan Permusyawaratan Desa antara lain: 
1. Minimnya pengetahuan dan pengalaman anggota BPD.

2. Pemahaman terhadap peraturan perundang-undangan tentang desa anggota BPD masih kurang.

3. Banyak anggota BPD yang tingkat pendidikannya rendah

4. Banyaknya peraturan perundangan yang menjadi pedoman dalam penyusunan peraturan di Desa sehingga para anggota BPD menemui kesulitan dalam pemahamannya sehingga menjadi hambatan.

5. Banyaknya jenis peraturan di desa seperti peraturan desa, peraturan bersama kepala desa dan peraturan kepala desa. (wawancara dengan I Wayan Wijaya BPD Bidang Pembangunan pada tanggal 3 April 2020).

Implementasi penyelenggaraan pemerintahan desa yang dilakukan oleh aparat pemerintah desa yang sesuai dengan Undang-Undang Nomor 6 Tahun 2014 Tentang Desa memiliki hambatan, Berdasarkan hasil wawancara dengan bapak I Wayan Wijaya BPD Bidang Pembangunan, yang mengatakan bahwa faktor-faktor yang menjadi hambatan fungsi Badan Permusyawaratan Desa, Diantaranya sebagai berikut:

1. Banyaknya jenis peraturan desa yang menjadi landasan/dasar hukum pembentukan peraturan desa seperti antara lain: Peraturan Pemerintah Nomor 43 Tahun 2014 tentang Peraturan Pelaksanaan Undang-Undang Nomor 6 Tahun 2014 tentang Desa, Peraturan Pemerintah Nomor 47 Tahun 2015 tentang Perubahan atas Peraturan Pemerintah Nomor 43 Tahun 2014, Peraturan Pemerintah Nomor 60 Tahun 2014 tentang Dana Desa yang bersumber dari APBN dan banyak lagi.

2. Sumber Daya Manusia

Sumber daya manusia yang tidak handal dan tidak berkompeten merupakan salah satu faktor penghambat dalam pelaksanaan fungsi BPD dalam pembentukan peraturan desa.

3. Partisipasi Masyarakat

Di Desa Sanding Kecamatan Tampaksiring Kabupaten gianyar yang menyatakan bahwa mekanisme perencanaan desa tersebut belum memperlihatkan sebagai bentuk perencanaan yang efektif karena partisipasi masyarakat rendah dan kurang berjalannya fungsi lembaga desa sehingga mengakibatkan tidak ada kesesuaian dengan kebutuhan desa. Maka ini menjadi penghambat dalam pelaksanaan fungsi BPD dalam pembentukan peraturan desa menjadi tidak sempurna atau tidak sesuai (wawancara dengan I Wayan Wijaya BPD Bidang Pembangunan pada tanggal 3 April 2020).

Lebih lanjut sesuai wawancara dengan I Dewa Ketut Raka Sekretaris BPD yang mengatakan, yang menjadi hambatan dalam pelaksanaan fungsi BPD dalam pengadaan barang dan jasa antara lain:

1. Kehadiran para anggota BPD dalam penyusunan/pembentukan peraturan desa rendah.

2. Pemahaman terhadap dasar hukum pembentukan peraturan desa juga masih rendah.

3. Permohonan terhadap potensi desanya juga masih rendah. (wawancara dengan I Dewa Ketut Raka, Sekretaris BPD pada tanggal 2 April 2020).

Terkait dengan upaya dalam mengatasi hambatan pelaksanaan fungsi Badan Permusyawaratan Desa, I Dewa Ketut Raka Sekretaris BPD mengatakan, yaitu :

1. Partisipasi masyarakat partisipasi masyarakatdalam pengambialn keputusan, perencanaan dan semua kegiatan didalam desa terhadap penggunaan dan pengelolaan dana desa serta pembentukan peraturan desa, keterlibatan ini penting agar penggunaan dan pengelolaannya bisa lebih tepat sasaran dan manfaatnya akan lebih mengenai dengan kepentingan riil dari masyarakat.

2. Kualitas sumber daya manusia

Kualitas sumber daya manusia (SDM) sangatlah penting, karena perencanaan dan pelaksanaan pembentukan peraturan desa tergantung pada SDM yang berkualitas. Kualitas sumber daya manusia yang ada pada setiap desa harus selalu diperhatikan oleh Kepala Desa selaku pemimpin desa karena pengaruhnya begitu besar dalam mensukseskan perencanaan dan pelaksanaan pembentukan peraturan desa agar pelaksanaannya berjalan secara efektif dan efisien. Dan guna menghasilkan laporan pertanggung jawaban dana desa yang baik.

3. Perencanaan

Perencanaan yang disusun haruslah sesuai dengan kebutuhan. Perencanaan merupukan suatu tujuan. 
Begitu pula Kepala Desa Sanding Kecamatan Tampaksiring menjelaskan bahwa: Banyak upayaupaya yang dilakukan untuk mengatasi hambatan pelaksanaan fungsi BPD seperti antara lain:

1. Mempertinggi volume kehadiran antara Kepala Desa beserta unsur desa dengan para anggota BPD, agar terjadi sinergi antara BPD dengan Kepala Desa.

2. Selain mengadakan pertemuan lebih intensif juga diupayakan adanya pertemuan rutin dan pertemuan insidentil (sewaktu-waktu bila diperlukan).

3. Selain pertemuan tersebut juga sering dihadirkan dalam acara-acara resmi penyelenggaraan desa seperti, arisan PKK, STT (Sekaa Teruna Teruni) dan organisasi lainnya yang ada di desa, BPD dan para Kepala Desa diupayakan hadir (wawancara dengan I Dewa Gde Mahendra, Kepala Desa Sanding, Kecamatan Tampaksiring Kabupaten Gianyar, tanggal 3 April 2020).

\section{SIMPULAN DAN SARAN}

\section{Simpulan}

Fungsi BPD dalam pembentukan PerDes antara lain Badan Permusyawaratan Desa (BPD) dapat menyusun dan mengusulkan rancangan Peraturan Desa tentang rencana pembangunan jangka menengah Desa, rancangan Peraturan Desa tentang rencana kerja Pemerintah Desa, rancangan Peraturan Desa tentang APB Desa dan rancangan Peraturan Desa tentang laporan Pertanggungjawaban realisasi pelaksanaan APB Desa. Rancangan Peraturan Desa dapat diusulkan oleh anggota BPD kepada pimpinan Badan Permusyawaratan Desa (BPD) untuk ditetapkan sebagai rancangan Peraturan Desa usulan Badan Permusyawaratan Desa (BPD). Adapun hambatan pelaksanaan fungsi Badan Permusyawaratan Desa dalam pembentukan peraturan Desa antara lain terdapat 2 hambatan yaitu pertama hambatan secara yuridis antara lain minimnya pengetahuan dan pengalaman anggota BPD, Pemahaman terhadap peraturan perundang-undangan tentang desa anggota BPD masih kurang, Banyak anggota BPD yang tingkat pendidikannya rendah, Banyaknya peraturan perundangan yang menjadi pedoman dalam penyusunan peraturan di Desa sehingga para anggota BPD menemui kesulitan dalam pemahamannya sehingga menjadi hambatan, Banyaknya jenis peraturan di desa seperti peraturan desa, peraturan bersama kepala desa dan peraturan kepala desa. Kedua, secara non yuridis yaitu Kehadiran para anggota BPD dalam penyusunan/pembentukan peraturan desa rendah, Pemahaman terhadap dasar hukum pembentukan peraturan desa juga masih rendah dan Permohonan terhadap potensi desanya juga masih rendah.

\section{Saran}

Kepada BPD disarankan untuk benar-benar menyerap aspirasi masyarakat desa, agar dalam penetapan APBD Desa sesuai dengan aspirasi dan potensi desa tersebut. Kepada Kepala Desa disarankan agar dalam penyusunan Peraturan Desa, tetap mengacu pada Undang-Undang tentang Desa dan Potensi Desa, agar tidak melenceng dari keadaan desa tersebut sehingga Undang-Undang Desa dapat berjalan dengan efektif.

\section{DAFTAR PUSTAKA}

Fauzan, A. (2010). Implementasi Peraturan Pemerintah No 72 Tahun 2005 Tentang Desa Terkait dengan Peran Bandan Permusyawaratan Desa dalam Penyusunan dan Penerapan Peraturan Daerah di Kecamatan Wanasari Kabupaten Brebes. Universitas Diponegoro.

Fauziah, L. A. (2020). Implementasi Badan Permusyawaratan Desa (BPD) dalam Pembahasan dan Penetapan Peraturan Desa. Al-Balad: Journal of Constitutional Law, 2(2), 1-12.

Kushandajani. (2008). Otonomi Desa Berbasis Modal Sosial Dalam Perspektif Socio Legal. Jurusan Ilmu Pemerintah FISIP Undip, Semarang.

Malik, S. (2020). Peran Badan Permusyawaratan Desa dalam Penyelenggaraan Pemerintahan Desa. Jurnal IUS Constituendum, 5(2), 325-343.

Patrasius. (2019). Pelaksanaan Fungsi Badan Permusyawaratan Desa (BPD) di Desa Loa Duri Ulu Kecamatan Loa Janan Kabupaten Kutai Kartanegara. Journal Ilmu Pemerintahan, 7(4), 7331742.

Rodhiyah, S., \& Harir, M. (2016). Peranan Badan Permusyawaratan Desa (BPD) dalam Pembentukan Peraturan Desa di Desa Krandon Kecamatan Guntur Kabupaten Demak. Jurnal Pembaharuan Hukum, 3(3), 291-300. 
Setiawati. (2018). Peran Badan Permusyawaratan Desa dalam Penyusunan dan Penetapan Peraturan Desa. Jurnal Pendidikan Kewarganegaraan, 5(1), 61-84.

Soekanto, S. (1986). Pengantar Penelitian Hukum. UI Press, Jakarta.

Wasistiono, S., \& Tahir, M. I. (2006). Prospek Pembangunan Desa. Fokusmedia, Bandung.

Wijaya, H. (2004). Otonomi Desa Merupakan Otonomi yang Asli, Bulat dan Utuh. PT Raja Grafido Persada, Jakarta. 